\title{
The Medium of Music
}

\author{
Alić S* \\ University North, Croatia
}

\section{Research Article}

Volume 4 Issue 1

Received Date: March 03, 2021

Published Date: March 25, 2021

DOI: $10.23880 /$ phij-16000168

Koprivnica, Croatia, Tel: 00385989828592; Email: salic@unin.hr

\section{Abstract}

The text analyzes the media dimension of music. This involves questioning the relationship between oral and music, the concept of man and his predispositions, as well as the important places of music history and the important places of reflection on music. The text seeks to show the importance of music throughout history, but also the most important, which is often forgotten: Music is the medium.

In what ways? This text attempts to answer that question.

Keywords: Music; Medium; Oral: Counterpoint; Wagner; Mozart; Bach; Nietzsche; Platoharmony

\section{Man and his media predispositions}

The articulation of the human voice - its separation from the babel of noises - marks the beginning of the odyssey of man. The voice acquires meaning. The passage of air through the throat, done according to the rules of meaningful formation, has enabled the voice to communicate with similar voices, to name objects, people and phenomena and to create the medium of language, which is more operable than mimics, gesticulation, body language and all other 'languages' preceding the spoken language.

The voice was the 'carrier' of meaning, a medium that gave birth to the man of the new culture, a photograph that preceded the invention of photography and the first ever video recording. The voice empowered us to escape from our surroundings. We began to find common ground in differences and to recognise both relations between voices and relations between voices and objects around us. ${ }^{1}$

1 Cassirer's analysis of anthropological research shows that the voice appears at the very beginning of the mythological explanation of the world: 'The oldest Egyptian texts tell us that Tum-Ra, the creator god, formed the gods, who are the original ancestors of all living creatures, in a human manner by an emission of sperm, or that he spat the first pair of gods from his mouth. But very early another more "spiritual" view emerges in the Pyramid Texts. The act of creation is no longer designated by a single
In Understanding Media, McLuhan notes: 'By means of translation of immediate sense experience into vocal symbols the entire world can be evoked and retrieved at any instant'.2

The harmony ${ }^{3}$ of the world was symbolised to us by the harmony of our well-tuned voices, which we offered, together with dance, as gifts to gods, who more or less resided among us. The voice as the carrier of meaning was a platform that managed tones, rhythm and body movements. As Hegel states in his Aesthetics, the music of the human voice is a natural gift, the only music that does not require any external material (which is needed, for example, in

material image; now the creator uses no instrument other than the power of his will, which is concentrated in that of his voice and his word.' Ernst Cassirer, The Philosophy of Symbolic Forms II: Mythical Thought, Oxford University Press, 1955, p. 210.

2 Marshall McLuhan, Understanding Media: The Extensions of Man, Routledge \& Kegan Paul Ltd, London, 1975, p. 57.

3 According to the ancient myth, Harmony was the wife of Cadmus, the king of Thebes, who, having killed the dragon guarding a spring near Thebes, sowed its teeth in the garden, from which there sprang armed men. McLuhan interprets these armed men as a metaphor for the alphabet that defined the fate of western civilisation. It is noteworthy that in ancient Egypt Ma' at was the goddess of harmony. Pythagoras, who studied in Egypt, brought many Egyptian ideas to the Greeks, including the idea of harmonious relations that could be reduced to number relations. 


\section{Philosophy International Journal}

architecture, sculpture, painting and instrumental music) ${ }^{4}$. Hegel also describes the human voice as 'the sounding of the soul itself'. ${ }^{5}$

In a similar vein, Hartmann in his Aesthetics uses, among other things, the dynamics, dramaturgy and timbre of the voice to exemplify the existence of the emotional level in the art of music, proving that the spiritual and musical worlds are not heterogeneous. ${ }^{6}$

In the text Negative Semiologie der Stimme. Reflexionen über die Stimme als Medium der Sprache, Sybille Krämer reemphasises this origin of the voice, showing a dimension that philosophy did not reckon with and now has to revise. ${ }^{7}$

An echo of the primordial source of harmony (reverberating through the voice and the tones of instruments imitating the voice) can be detected in Plato's understanding of mousike. Building on his predecessors, primarily Pythagoras and his school, Plato emphasises the importance of the voice within the Greek notion of music and the advantage of the voice (speech) over the melody and speech rate. ${ }^{8}$ Has Plato been correctly interpreted, with all dimensions of his understanding of mousike taken into account? Is Friedrich Nitzsche exaggerating when he summarises his view presented in The Birth of Tragedy from the Spirit of Music in Twilight of the Idols: 'I recognized Socrates and Plato as symptoms of decay, as instruments of the Greek dissolution, as pseudo-Greek, as anti-Greek (Birth

4 GWF Hegel, Aesthetics/Lectures on Fine Art, translated by T. M. Knox, vol. II, Oxford at the Clarendon Press, 1975, p. 919.

5 'Thirdly, we may specify as the freest, and in its sound the most perfect instrument the human voice, which unites in itself the character of wind and string instruments because in this case it is a column of air which vibrates, while through the muscles there also comes into play the principle of tightly stretched strings.' GWF Hegel, Aesthetics/ Lectures on Fine art, translated by TM Knox, vol. II, Oxford at the Clarendon Press, I975, p. 922

6 Chapter 14, Strata in Musical Composition, Nicolai Hartmann, Aesthetics, De Gruyter, 2017, p. 211-224.

7 'Die erste menschliche Lebensäußerung ist der Schrei. Symptom dafür, daß wir atmen, also leben. „Leblose Dinge haben keine Stimme“, stellt Aristoteles fest. In der phonischen Aktivität wird unser Körper zum, Stimmapparat', zum Instrument: Ein durch Lungen und Bronchien geformter Luftstrom, der unsere Stimmbänder in Schwingungen versetzt und durch deren Vibration Töne erzeugt. (...) Der ,Ort' der Stimme ist die Aktivität des sie erzeugenden Leibes. Die Stimme ist die Spur des Körpers im Sprechen. Das aber heißt: Der Körper zeigt sich in der Stimme.' https:// www.geisteswissenschaften.fu-berlin.de/.../PDFs...

8 In Peter Kivy's opinion, it is relatively easy to connect music with emotional speech (as Plato did), but it should be kept in mind that at the time the voice usually accompanied a melody played on an instrument, except in the case of vocal music. In the 16th century, this was confirmed by the Florentine Camerata, a Florentine society that propounded the revival of ancient Greek recitative drama. For more information, see Kivy, Peter, Introduction to a Philosophy of Music, Oxford University Press, 2010, pp. 50 and 164 of Tragedy, 1872).9

Nietzsche is ambivalent about music and about Socrates and Plato (as well as about his great friend Richard Wagner, to whom he dedicated The Birth of Tragedy). He, on the one hand, recognises a tragedy of separation in the birth of tragedy. The dramatic element (and dramaturgy is always about petty human passions and the like) will overpower the musical element, with the latter representing a unique correlation between the world, meaning, voice, gods and people. On the other hand, it is precisely tragedy that Nietzsche sees as comprising the significance and greatness of art, which reconcile all dualities, including the duality of the human and the divine.

The young Wagner emphasises that music, before it declined into drama, had been an area of the ideal human community providing instructions for various fields of human culture. Drama dissociated itself from music and dissolved into rhetoric, sculpture, painting, instrumental music, etc. The time when music taught us and when it was the conscience of the humanity was succeeded by the time when architects construct military barracks, painters portray despicable millionaires, poets write poems appealing to the general or critical taste and musicians compose for dances. ${ }^{10}$

However, it is interesting that Stravinsky, for instance, criticised Wagner's 'dramaturgical' influences on music that lasted the following fifty years: 'Whether we admit it or not, the Wagnerian drama reveals continual bombast. Its brilliant improvisations inflate the symphony beyond all proportion and give it less real substance than the invention, at once modest and aristocratic, that blossoms forth on every page of Verdi. ${ }^{\prime 1}$

The gaps being established between our ideas (and even the established forms of human community) have been strongly supported by their own artillery, in this case the media, which have elevated them to self-awareness (as was also the case before). In this regard, the human interpretation, including that of the ancient Greeks, which assigns priority to the voice over the rhythm or melody is partly due to fear that in the opposite case meaning would no longer dominate

9 Friedrich Nietzsche, Twilight of the Idols, or How to Philosophize with the Hammer, translated by Richard Polt, introduction by Tracy Strong, Hackett Publishing Company, Inc., Indianapolis/Cambridge, 1997, p. 12.

10 'The Drama separated into its component parts; rhetoric, sculpture, painting, music, \&c., forsook the ranks in which they had moved in unison before; each one to take its own way, and in lonely self-sufficiency to pursue its own development. And thus it was that at the Renaissance of Art we lit first upon these isolated Grecian arts, which had sprung from the wreck of Tragedy.', Richard Wagner, Art and Revolution, Wagner Library, p. 21.

11 Igor Stravinsky, Poetic of Music, Harvard University Press, Cambridge, 1947, p. 61. 


\section{Philosophy International Journal}

and harmony would be reduced merely to pleasant sounding tones. If the rhythm and melody overpowered the voice, the seductive power of music detached from the highest meaning of harmony, and the meaning of human existence, would lead the mankind to a world of broken relationships and superficial games of seduction and manipulation. ${ }^{12}$ Unfortunately, this is exactly what happened..$^{13}$

Music is nowadays, like language, engraving, woodcut or painting, like photography or numbers - at the same time something that we live (within sensory relationships) and something that metaphorically intermediates between (symbolises/mediates) the world of human senses and the world of human ideas (the highest being the one defined by universality or God). Music is both $\alpha \rho \mu$ ovía pleasing to the human ear and an instrument that has made man more aware that the universe as $\alpha \rho \mu$ oví $\alpha$ (through music) is opening to the human mind.

Music (and a number of phenomena of human culture) can be considered not only as a human product (an element of ethos, culture, produced by a voice and/or an instrument), but also as a source of relations and rules suggesting to humans how to think and live, that is, how to understand that they exist, what they exist in and how. Which line of consideration are we going to follow?

Hegel circumvented the Greek understanding of harmony. He placed this manner of reasoning in the symbolic form of art, on the level that is to a large extent connected with religion or pre-religion mythological patterns that merge 'general and direct sensuousness' ${ }^{14}$ in a form that is

12 Plato is well aware of the strength of art, poetry and, most of all, music. In The Republic he, inter alia, states: 'So, Glaucon,' I said, 'isn't this why the rearing in music is most sovereign? Because rhythm and harmony most of all insinuate themselves into the inmost part of the soul and most vigorously lay hold of it in bringing grace with them; and they make a man graceful if he is correctly reared, if not, the opposite.' Plato, The Republic, second edition, translated with notes and an interpretive essay by Allan Bloom, BasicBooks, a division of HarperCoWmsPublishers, (402 e), 1991, p. 80.

13 Plato warned of the effect of music on those who completely surrendered to it: 'Then, when a man gives himself to music and lets the flute play and pour into his soul through his ears, as it were into a funnel-using those sweet, soft, wailing harmonies we were just speaking of-and spends his whole life humming and exulting in song, at first, whatever spiritedness he had, he softened like iron and made useful from having been useless and hard. But when he keeps at it without letting up and charms his spirit, he, as the next step, already begins to melt and liquefy his spirit, until he dissolves it completely and cuts out, as it were, the sinews from his soul and makes it "a feeble warrior"'. (XVIII b.), Plato, The Republic, second edition, translated with notes and an interpretive essay by Allan Bloom, BasicBooks, A Division of HarperCoWmsPublishers, (411 a), 1991, p. 90.

14 It is indicative that this kind of 'harmonious' union is discussed in Chapter I. Unconscious Symbolism, in Section I. The Symbolic Form of Art, G. W. F. Hegel, Aesthetics/Lectures on Fine Art, translated by T. M. Knox, vol. I, Oxford at the Clarendon Press, 1975, p. 323 and cont. not adequately intermediated by reasoning. ${ }^{15}$

However, this dilemma has outlived him. We are still uncertain whether music is a resonating harmony of the universe, a symbol and an inducement to get closer to truth or whether it should be analysed as an outcome of social and cultural circumstances and, as such, understood as a product of culture in the whole range of its manifestations? Naturally, the question is also whether these are the only options and whether the awareness of harmony declining into the prose of dramaturgical plots of modern soap operas opens a new possibility to comprehend the ancient Greek understanding of music and even a possibility for philosophy to embrace a different understanding of music. This text aims to give answers to these questions.

\section{Music as 'The Supreme Philosophy'}

Plato considers music to be a medium of wisdom, having defined it as the supreme philosophy (philosophy being the love of wisdom). $\alpha \rho \mu$ ovía, therefore, establishes the type of harmony that should characterise every kind of reasoning that has risen to the level of wisdom.

Naturally, the context is also important. Plato expresses this formulation in the Phaedo, embedding it in Socrates' explanation, which is indicative and gives rise to several lines of thinking. Socrates was in his dream visited by the Muses, who reminded him that he should be practising the art of the Muses. Socrates obeys the dream as it is a 'sacred duty'. Although he believes that he has already been creating music, philosophy being the supreme music, he decides to take up music as a sensory phenomenon. ${ }^{16}$

Despite his defining music as 'the supreme philosophy', Plato is obviously aware that this can only be a metaphorical definition of harmony, which has to be achieved in reasoning in order to enable a harmonious life. The Muses, therefore, lead Socrates (Plato) away from the universal order, expressible by music, towards creating concrete music.

15 He speaks of music as a romantic art -'the art of the soul/heart'. The reliance on the sense of hearing in music enables listening to one's inner self, that is, to spirituality as such: 'The same is true of the effect of music. What it claims as its own is the depth of a person's inner life as such; it is the art of the soul and is directly addressed to the soul., G. W. F. Hegel, Aesthetics/ Lectures on Fine Art, translated by T. M. Knox, vol. II, Oxford at the Clarendon Press, 1975, p. 891.

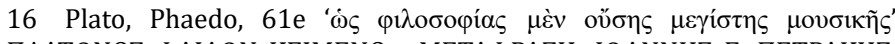
$\Pi \Lambda A T \Omega N O \Sigma$ ФAI $\Delta \Omega N$ KEIMENO - METAФPA $\Sigma H: ~ I \Omega A N N H \Sigma$ E. ПETPAKH $\Sigma$,

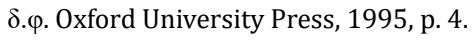

'I supposed that the dream was encouraging me to create the music at which I was working already, for I thought that philosophy was the biggest music, and my life was spent in philosophy. 'Plato's Phaedo, translated by F. J. Church, The Liberal Arts Press, New York, p. 4/5. 


\section{Philosophy International Journal}

His idea will be later developed by Schopenhauer. Few philosophers have assigned such significance to music as this Kant's successor, and the successor of Plato's understanding of art in general and music in particular: 'The (Platonic) Ideas are the adequate objectification of the will. To stimulate the knowledge of these by depicting individual things (for works of art are themselves always such) is the aim of all the other arts (and is possible with a corresponding change in the knowing subject). Hence all of them objectify the will only indirectly, in other words, by means of the Ideas. As our world is nothing but the phenomenon or appearance of the Ideas in plurality through entrance into the principium individuationis (the form of knowledge possible to the individual as such), music, since it passes over the Ideas, is also quite independent of the phenomenal world, positively ignores it, and, to a certain extent, could still exist even if there were no world at all, which cannot be said of the other arts. $^{17}$

Language is a medium of everyday life, but it is also a medium of poetry, science, philosophy, theology and even of mysticism. Numbers, while used as the symbols of our business relations, also express the relations of musical tones or the golden ratio in painting, acquiring an inspiring dimension of potential keys to the door of universal knowledge. Music is thus both an object of the entertainment industry and a medium that poses the question of whether $\alpha \rho \mu o v i ́ \alpha$ represents a resounding symbol of the order of the Omnipresent, based on eternal ratios, which are hidden, but emerge in the manifest world through the media suggesting the awareness of that order.

Schopenhauer defines music in his own way, i.e., in keeping with his own system of reasoning, like Plato, as the supreme art, true philosophy. ${ }^{18}$ Music is therefore a direct objectivation and reflection of the will, which corresponds with Plato's idea and Kant's thing-in-itself. As the existing world is merely the objectivation of the will, Schopenhauer believes that music would exist even if there was no world. ${ }^{19}$

17 Arthur Schopenhauer, The World As Will And Idea, translated from German by R. B. Haldane, M.A. and J. Kemp, M.A. p. 257

18 'Further, according to my view and contention, philosophy is nothing but a complete and accurate repetition or expression of the nature of the world in very general concepts, for only in such is it possible to get a view of that whole nature which will everywhere be adequate and applicable. Thus, whoever has followed me and entered into my mode of thought, will not think it so very paradoxical if I say, that supposing it were possible to give a perfectly accurate, complete explanation of music, extending even to particulars, that is to say, a detailed repetition in concepts of what it expresses, this would also be a sufficient repetition and explanation of the world in concepts, or at least entirely parallel to such an explanation, and thus it would be the true philosophy' Arthur Schopenhauer, The World As Will And Idea, translated from German By R. B. Haldane, M.A. and J. Kemp, M.A. p. 345.

19 Ibid. 336.
The phenomenon of $\alpha \rho \mu o v i ́ \alpha$ (as a visible and mathematically demonstrable order in music, which has an impact on the human psyche) made the Greeks believe into the idea of bringing order to the human society. It seemed that the only thing to do was to take musical harmony seriously: not only to experience it, but to think and live it in a specific way.

Perceptible by senses and mathematically demonstrable, the order in music was something like a divine voice, a message to us humans saying that we could be the measure of all things, that we should look beyond the mundane and search for answers about the meaning of existence in eternity, which can be expressed by a medium containing all these relations like a hidden key.

There is always a danger that harmony could be understood as a metaphysically determined, predestined, eternal order that man comprehends according to the rules of the physical, natural order. This possibility is exploited in an interesting way by Gianluca Giannini in his text 'We can Build You'! Some Reflections about Human Fate and Vocation. ${ }^{20}$

Unfortunately, thought cannot be found in music in the same way as it can be found by faith. The reflection about an object and the object of reflection are two separate phenomena. We can choose at any given moment, but we choose only one. Intelligence and sensuousness do not unite in music, as Plotinus thought. ${ }^{21}$

Specifically, man can be aware of the order in music, arithmetic or geometry, but this does not result in the constant awareness of universality. This point can be illustrated by La Marseillaise or Scottish bagpipes, and even by the trumpets of Jericho and their ability to encourage warriors. Hegel ironically states that it would take quite a lot of trumpets to bring down a fortress, adding: 'It is enthusiastic ideas, cannon, the genius of generals which achieve this now, and not music, for music can only count as a support for those

20 The author writes about 'the metaphysical pretensions of traditional humanism' and 'the metaphysical totalism of anthropocentric origin', adding: 'But the epochality of our historical period is the abandonment of any kind of metaphysical safety, of a totalism in which every tiny fact necessarily has its place and order.' Gianluca Giannini, 'We can Build You'! Some Reflections about Human Fate and Vocation, in Philosophy International Journal, Medwin Publishers, 2019. p. 12.

21 'For how could there be a musician who sees the melody in the realm of Nous and is not stirred when he hears the melody of sensible sounds? Or how could there be anyone skilled in geometry and the science of numbers who is not pleased when he sees right relation, proportion, and order with his bodily eyes? Of course, people do not look at the same things in the same way; some, when they are looking at pictures, see the works of art with their eyes but recognize in them an imitation in the world of sense of the reality existing in Nous, and are excited by it and come to a recollection of the truth.' II. 9. 16. PLOTINUS by A. H. ARMSTRONG, LONDON, GEORGE ALLEN \& UNWIN LTD, Ruskin House Museum Street, p. 144. 
powers which in other ways have already filled and captured the mind'22.

Music is a medium that both symbolises order and creates musical order. It can be used as a metaphor for the universal order or the order of the universe, but such a metaphor is too human not to start living its own life as an object of the entertainment industry.

Reflecting on music and harmony, Plotinus, among other things, notes the following: 'For who that truly perceives the harmony of the Intellectual Realm could fail, if he has any bent towards music, to answer to the harmony in sensible sounds? What geometrician or arithmetician could fail to take pleasure in the symmetries, correspondences and principles of order observed in visible things? Consider, even, the case of pictures: those seeing by the bodily sense the productions of the art of painting do not see the one thing in the one only way; they are deeply stirred by recognizing in the objects depicted to the eyes the presentation of what lies in the idea, and so are called to recollection of the truth - the very experience out of which Love rises. ${ }^{23}$

'The recollection of truth by means of music' is in fact an unconscious expression of the view on the necessity of including human emotions in the concept of truth. The conceptual truth, devoid of human emotions, is just the truth of words as such, leading to textual hierarchy that, in turn, gives rise to human hierarchy. Lazy thinking tends to convert metaphors into the laws of reality. That is why it is important to distinguish between the characteristics of music belonging to the metaphor, symbol, sign and mathematics from those belonging to the human need to finally discover a universal key to knowledge.

Mike Sandbothe underscores the pragmatic dimension of the media in general in his book in which he refers to Nietzsche and his criticism of 'purely' theoretical knowledge aimed at enabling access to the horizon of theoretical truth: 'Nietzsche also undermined the theoreticist view of language, truth, and knowledge with pragmatic recourse to determinations of usefulness and relations of interest. Thus he emphasized in relation to truth and knowledge: "We simply have no organ for knowing, for "truth": we "know" (or believe or imagine) exactly as much as is useful to the human herd, to the species [...]'. (Nietzsche 2001, 214 [§354]) $)^{24}$

22 GWF Hegel, Aesthetics/ Lectures on Fine Art, translated by T. M. Knox, vol. II, Oxford

at the Clarendon Press, I975., p. 909.

23 Plotinus: The Six Enneads, translated by Stephen MacKenna and B. S. Page, Second Tractate. On Providence (16).

24 Mike Sandbothe, Pragmatic Media Philosophy: Foundations of a New Discipline in the Internet Age, translated by Andrew Inkpin, Online Publication: www.sandbothe.net, 2005, p 90.
The concept of music as the supreme philosophy (Plato) implies that only one possible kind of intellectual listening, involving a specific type of music, can remind us of the universal order. ${ }^{25}$ This order is also proposed by geometry, arithmetic, dance, the golden ratio and astronomy. However, what happens when music, which balances between spirituality and corporeality, focuses only on corporeality? Plotinus and his successors believe that unmusical people listen to such music. And vice versa, unmusical people can be said to listen to music detached from its intellectual, philosophical background. Unmusical people are therefore unintellectual people, people who experience music, geometry and other carriers of keys to understanding of the order of logos in a practical and superficial way.

The concept of the ancient Greek singer who had to be inspired by god in order to be able to sing is later to be found in religious approaches to the word and voice. For example, the Orthodox liturgy relies on the voice, whereas Islam shows heightened scepticism towards vocal and instrumental music. Islamic songs, illahis, are sung by divine people, people inspired by divine greatness. However, it is worth mentioning that Al-Farabi, Al-Ghazali and other Islamic thinkers wrote about the therapeutic power of music, and that in the Ottoman Empire there was a special type of hospital - hastahana - which provided musical therapy, that is, therapy by the sounds of the ney and similar natural instruments. ${ }^{26}$

\section{Artistic Formation of Truth}

It is noteworthy that Mozart, as a child, covered the walls of his parental house with chalk figures, solving mathematical tasks, and that he effortlessly acquired the linguistic structures of French, Italian or English, which he learned at a very early age.

25 Music has a pragmatic purpose and it is useful for the education of warriors. Its harmony should help us to bring guardians' bodies into balance. Rhythm and melodies were supposed to make an impact on guardians' bodies, but not by transferring knowledge through music: 'But it,' he said, 'was the antistrophe to gymnastic, if you remember. It educated the guardians through habits, transmitting by harmony a certain harmoniousness, not knowledge, and by rhythm a certain rhythmicalness. And connected with it were certain other habits, akin to these, conveyed by speeches, whether they were tales or speeches of a truer sort.' Plato, The Republic, second edition, translated with notes and an interpretive essay by Allan Bloom, BasicBooks, A Division of HarperCoWmsPublishers, (522 a) 1991, p. 200.

26 The sound healing tradition is very old. The Aborigines used the didgeridoo. The gong and wind chimes were used in the Far East and bamboo or ivory flutes in South America. Singing bowls are part of the inventory of Buddhist temples. The djembe, a type of drum originating from West Africa, is still appreciated and used in ethno music. Pythagoras explored sound by means of the monochord. The Tibetan bowl is very often used in alternative healing sessions. 


\section{Philosophy International Journal}

Mozart's genius very early mastered the structures (sometimes similar or analogous) of linguistic, mathematical and musical relations. A lesson to be learned from this information about his youth could be that it is easier to learn everything than to learn part by part. A deeper lesson could be that there are deep connections between various areas of human knowledge originating from the forgotten ground of universal harmony, which, having exploded in ancient Greece, disintegrated into the knowledge of writers, dramatists, musicians, actors, dancers, priests, philosophers, scientists... ${ }^{27}$

The child prodigy and the genius who remained a child sensed the connections between things and drew his inspiration from them. He resisted the norms in which he recognised lies, ideology and death. Either that or he simply perceived or had a developed sense of convergence, which Hartmann analyses in his Aesthetics, making reference to Mozart in this context: "This process of convergence expresses itself in no other way than this: we experience what is otherwise heterogeneous nonetheless as kindred. Thus the Parthenon and J.S. Bach's Art of the Fugue, the ceiling of the Sistine Chapel (perhaps in the figures of youths or of the Prophets) and Shakespeare's Henry IV (including the figure of Falstaff), Rembrandt's self-portrait in old age (Amsterdam) and the Apolo on the pediment (of the temple of Zeus) at Olympia, Beethoven's fifth or seventh symphony...28

Socialisation inevitably leads to the acceptance of social norms. Mozart was always often criticised for his lack of independence and poor social skills, but this alleged weakness of his was actually the proof of his sincere and fruitful efforts to remain until the end on the free horizon of musical creation. Only the person who is as much as possible liberated from the prescribed norms of the hypocritical society can drink from the eternal well of universal harmony.

One should also bear in mind that this musical magician occasionally had to be his own producer. For example, he made all the arrangements for the performance of Piano Concertos No. 21 and 22 on his own, including hiring the musicians and concert promotion. In his doctoral thesis Mozart and the Practice of Sacred Music 1781-91, David Ian Black confirms that Mozart really was in an unenviable

27 From the time of Wagner, who stated that he recognised the hypocrisy of the rich, as well as of the Church, and that the Art submitted/sold itself to the trade, emphasising the difference between such a role of the art in society and the role it played in ancient Greece, when the poet, as a 'divine priest' used to lead the dancers and the choir, speaking the words of divine wisdom: 'Such a tragedy-day was a Feast of the God; for here the god spoke clearly and intelligibly forth, and the poet, as his high-priest, stood real and embodied in his- art-work, led the measures of the dance, raised the voices to a choir, and in ringing words proclaimed the utterances of godlike wisdom.' Richard Wagner, Art and Revolution, Wagner Library, p. 12.

28 Nicolai Hartmann, Aesthetics, De Gruyter, 2017, p. 497. situation: 'An ambitious series of subscription concerts such as those put on by Mozart in the 1780s must have required a considerable number of instrumentalists. Little is known at this stage about how Mozart went about recruiting these performers. $^{29}$

Indeed, Mozart's music is like a miraculous well, which, always the same and always different, swells and ebbs, plays with the water flowing out of it and seems to be touching pebbles at precisely the right moments, producing the same tone in different ones and vice versa. It appears that the mathematic, linguistic and musical elements flow into a vivacious musical picture of harmonious relations and (potential or discovered) beauty. ${ }^{30}$

Most modern age musicians, providing that they can rise to the level of the beginning of Mozart's Symphony No. 40 in G minor, would exploit this idea to an extreme. But Mozart did not do that. He always took a step forward in his variations, teaching us that we always start all over again and that room for discovering beauty and being creative is infinite. These tones thus also suggest that the potentials of his world - and the potentials of our world - may also be infinite.

Logic in Mozart's music acquires an audible, auditory dimension. His musical reasoning resembles a postponed conclusion that is not reached even when the composition ends. Mozart's music seems to implement an axiom about an eternal, prosperous and beautiful life that is difficult to put into words and can only be approached by music. It is therefore no wonder that Schopenhauer liked Mozart's music and that he preferred it to the music of Wagner, who appreciated him very much. Schopenhauer even told Wagner to give up music and take up writing. ${ }^{31}$

Mozart explores, varies, enters every nook and cranny, changes rhythms, melodies, instruments, tempo and harmony. He is like a child who is still capable of seeing

29 David Ian Black Mozart and the Practice of Sacred Music 1781-91, Harvard University Cambridge, Massachusetts, April 2007, p. 49.

30 The beauty of Mozart's music evokes words that interpret this beauty as an invitation to universality. However, Mozart was a concrete person, who during his burdensome life had to adjust his music to market demands and commissioners' requests. This is why both the personality and the oeuvre of this musical genius lead to various interpretations of his music. Mozart's music seems to contain the universal music - a symbol of the overall harmony, the language of language, the medium of media - but the way he lived his life shows the reality in which he worked. This context makes us more realistic and requires from us to reflect on music in terms of sociology of music, or mediology.

31 Schopenhauer's philosophy of music was influential in the works of Richard Wagner. Wagner was an enthusiastic reader of Schopenhauer, and recommended the reading of Schopenhauer to his friends. Schopenhauer himself, however, preferred the transparent music of Mozart and that of Rossini to the music of Wagner that engulfs the listener in its passion. https://www.newworldencyclopedia.org/entry/Arthur_Schopenhauer 


\section{Philosophy International Journal}

spiritual beings and playing with them.

He lived a hard life and yet he pushed himself to the limit. Unfortunately, or luckily, only the best was (nearly) enough for the Salzburg genius. He was not meant to spend his life composing at ease in a well-off bourgeois family. He was sentenced to creativity and he served his sentence in a most magnificent way.

When listening to Symphony No. 25 in G minor, one cannot help recalling Mozart's letter to his father in which he explains his search for 'the golden mean'. The composition should not be too complicated and it had to be pleasing to the ear, but it also had to contain passages clearly indicating that its author, although he could have been more inspiring or profound, wished to embrace as many people as possible by his music and introduce them into its 'musical ratio'.

And Mozart succeeded in that. The beginning of Symphony No. 25 is like a child's play; bouncy, playful, promising ... It seduces the listener into getting acquainted with a genius who will reveal his whole depth later on, through the entirety of musical logic presented to his listeners. In a similar, but still different way, Symphony No. 41 (named Jupiter Symphony) opens with a seductive, imposing strength, only to expose its gentle interior later on.

Mozart's music is characterised by surprises, new beginnings and reversals, it comes from a soul that is both childishly playful and glorious - and what is more - well aware of that.

While Mozart signified freedom and beauty, Bach was regarded as a composer whose works could replace theological or philosophical proof of the existence of god. Cioran, for example, noted: 'Many theologists and philosophers who were trying day in and day out to find arguments for the existence of god overlooked the only valid argument: Bach. ${ }^{32}$

This great artist's music is so taken as proof of the existence of the transcendental almighty creator - god. But this has not always been so, and definitely not during Bach's time. In 1703, when he took the position of organist in Arnstadt he very soon met with an unfavourable reception not only from the consistory, but from the clergy too. The consistory thought it unacceptable for the young Bach to play in concerts in other towns without their approval, while the clergy found his chorals complicated. ${ }^{33}$

32 Sioran, Emil, o bogu, o muzici, o ljubavi, Edicija Braničevo, Požarevac, 2010, p. 56.

33 Bach was on a life-long search for a place where he could devote himself to music. The music that burst through him was all too easily
Apparently, each period in history has an audience with its own taste for arguments about the existence of god. Bach's contemporaries would probably not understand what Cioran meant when he said: 'Bach is everything. And what is everything? God himself. Because there is nothing in Bach that is not god. ${ }^{34}$

Bach is a message. He emanates divine harmony that tells man he can be a medium of that what is unspeakable and divine. Bach also signifies nostalgia for the times when music did not have to 'rise' to divinity, having been, as 'the musical element' part of that divine unity.

He was called the poet of music. Even though the title of the priest of musical celebration of god might have been more appropriate, in the context of these observations he clearly emerges as the one who did not resign himself to the role of common artist and tried to restore music to its divine glory.

Ludwig Van Beethoven took a similar path in life. Having to associate with the representatives of the feudal world, which he did not respect, convinced that Napoleon would destroy it - Beethoven found the universality of music in his effort to 'harmonise the world' with the beauty and strength of his music.

The belief in the power of reason demonstrated by the Enlightenment was to some extent the belief in the universe explained by reason. A transcendent god was replaced by reason, sacrosanct, but static. The Enlightenment announced changes, but made only perfunctory efforts to achieve them, which is hardly surprising as belief in progress only, or for the most part, reflected belief in technical advances, faster vessels, industrial machinery, colonial conquests and the amassing of wealth from all over the world into European capitals.

The initial strokes of Beethoven's Fifth Symphony announce a fight with fate. What fate had in store for the artist was disease, which made it difficult for him to compose, the feudal system where, in Beethoven's words, birthright was more important than merit, and condemnation to solitude, shunning people and spending time in nature.

Beethoven's Sixth Symphony (Pastoral) illustrates the ever-present impulse of the greatest musicians - divine presence in the creator. The harmony of universality

labelled as church music. The god of his music appeared to him through the counterpoint and inspired him and musicians from later periods by deeper and more elaborate music.

34 Sioran, Emil, O bogu, o muzici, o ljubavi, Edicija Braničevo, Požarevac, 2010, p. 56. 


\section{Philosophy International Journal}

is presented on the 'commonplace' material. Pastoral Symphony reflects the author's admiration of scenery as seen by the eyes of the common man. In this regard, musical Romanticism (as well as Romanticism in literature or arts) is the artistic expression of turmoil, expectations, hopes, and even of revolutionary developments. Beethoven was an inspiration to people, who will always in different ways celebrate their inner feeling and need to ascend to sublimity and eternity, which are infinitely larger than any individual or human life in general. Nietzsche, who criticised Beethoven's symbolism, would not have agreed with this view. ${ }^{35}$

In the introduction to his text on Beethoven's Seventh Symphony, Bèla Hamvas resolutely claims: 'To say the music of Beethoven is titanic is cliché. But it's true.'36

As regards the Ninth Symphony, it is indicative that Beethoven used the words of Schiller's Ode to Joy for it. Also important is an image that will forever remain as a memento of human effort: Beethoven, completely deaf, is sitting next to the conductor during the performance of his Ninth Symphony. The strength of his will gave birth to an immaculately conceived piece of music that relied on inner hearing, geometry of notes or resounding musical notation music born in the dungeon of silence.

The Enlightenment resonated more strongly and humanely with artists than with the rest of society. The romantic individualism was born precisely on the wings of optimism of the Enlightenment, borrowing the existential burden and willingness to change from the unhappy people.

We, humans, name grand things we are unfamiliar with. We believe that we understand them when we name them. We live in a universe, but we do not know what it is. We sense an order, but we do not know very much about it. We assume that everything that exists has been born once, but this is only because we have been born ourselves and tend to take a human perspective. We are like a tiny virus on a speck of dust in a remote part of something unthinkably large.

35 'There cannot therefore be any question as to a necessary relation between poem and music; for the two worlds brought here into connection are too strange to one another to enter into more than a superficial alliance; the song-text is just a symbol and stands to music in the same relation as the Egyptian hieroglyph of bravery did to the brave warrior himself. During the highest revelations of music we even feel involuntarily the crudeness of every figurative effort and of every emotion dragged in for purposes of analogy; for example, the last quartets of Beethoven quite put to shame all illustration and the entire realm of empiric reality. The symbol, in face of the god really revealing himself, has no longer any meaning; moreover it appears as an offensive superficiality.' Friedrich Nietzsche Early Greek Philosophy \& Other Essays, New York, The Macmillan Company, 1911, p. 37/38.

36 https://www.hamvasbela.org/2011/12/bela-hamvas-seventhsymphony-and.html
Still, if we cannot see, hear and think that far, and about that largeness, we rise to the level of the human form of selfunderstanding of that universe in the artistic works of the great sons of humanity. We are capable of composing the truth about the universe, although we do not possess the right means of understanding. We are like Beethoven, who turned deaf, but continued to compose magnificent music. We are active specks of dust that are capable of understanding that we exist only through symbols/media intermediating between us and the universe. In language we understand to quote Benjamin - the linguistic dimension of the universe ${ }^{37}$, and this can be applied to all other media intermediators.

One of the ways in which we exist is music. Like the gods of ancient Greece, who lived among the Greeks, showing them favour, and who, although immortal, had human destinies, the medium of music, this splendid intermediary between man and the universe, offers itself to us, seduces us, intoxicates us, leads us to wars, makes us fall in love and

37 'What does language communicate? It communicates the mental being corresponding to it. It is fundamental that this mental being communicates itself in language and not through language. Languages, therefore, have no By saying words out loud, in a way I certainly exist. Here and now and with no scepticism, by saying more or less articulate words, I prove: that I have decided to try and give myself true existence in a roundabout way through words that have their own meanings; that I have been educated, trained, disciplined, civilized, shaped... so that I don't question words as arguments in the legal process with the universal being. I also prove that I am part of some culture which sweeps most of its problems under the carpet, i.e. a civilization that in the name of its progress works on its self-destruction. I prove finally, and in an indirect way, that my being through words, sentences, grammar, logic, metaphors, metonymies, signs, symbols, buildings that rise up on the basis of all of these - is closest to that universal being. At the same time, I fear that each of my victories has served to distance me from the problem. The more I write, the less I try to remember, with the availability of transport options I walk less and less, confronted with all the happy endings in movies, I am less happy, with different human sentences of grammatical and logical interpretations of God, I am moving farther away from what this word should signify. The fact that we can calculate, right down to a millimetre, where and when in the Earth's orbit, or even further, two aircrafts sent by us humans from Earth will meet, proves the success that partly also signifies our failure. I live in a neighbourhood with people like me, who put the success of mathematics above everything, speaker, if this means someone who communicates through these languages... What is communicable in a mental entity is its linguistic entity. Language therefore communicates the particular linguistic being of things, but their mental being only insofar as this is directly included in their linguistic being, insofar as it is capable of being communicated.' Walter Benjamim: Selected Writings Volume 1 19131926, edited by Marcus Bullock and Michael W. Jennings, The Belknap Press of Harward University press, Cambridge, Massachusetts London, England, p. 4. 'Was teilt die Spracje mit? Sie teilt das ihr entsprechende geistige Wesen mit. Es ist fundamental zu wissen, dass dieses geistige Wesen sich in der Sprache mitteilt und nicht durch die Sprache. Es gibt also keinen Sprecher der Sprachen, wenn man damit den meinst, der durch diese Sprachen sich mitteilt. Das geistige Wesen teilt sch in einer Sprache und nicht durh eine Sprache mit - dass heist: es ist nicht von aussen gleich dem sprachlichen Wesen... Die Sprache teilt also jeweilige sprachliche Wesen der Dinge mit, ihr geistiges aber nur, sofern es unmitelbar im sprachlichen beschlossen liegt, sofern es mitteilbar ist.' Benjamin, Walter, Über Sprache überhaupt und über die Sprache des Menschen, Gesammelte Schriften, Band II-1, Suhrkamp Verlag, Frankfurt am Main, 1977, pp: 142. 


\section{Philosophy International Journal}

exalts us...

The questioning of the idea of god, the fundamental concept of the overall human thought, has approached the area of questioning the media as intermediators between man - a virus on a speck of dust in the universe - and the universe. Can the majestic music of a deaf man answer the millennia-old questions of the philosophy of music?

Is man the measure of all things or a being so lucky as to fit into the measure of all things? The one who stands in the middle divides the area into two parts. Each part becomes a separate unit. If these areas could produce sounds, they would be an octave higher than those of the whole area.

Sound is a ratio visible by hearing. In tones we hear ratios that reflect the primordial order. That order is what enables us visual or auditory submersion in them - these ratios. We are not aware of that. We act like children who freely and playfully run between tables unheeding their sharp corners. The beauty of the play creates the magic of happiness.

We are the measure of measured and balanced relations. We are the conscience of harmony, which is the audible or visible part of the order of relations of the Omnipresent. We have transformed the message of the universe into our own pleasure. We dive into the world of tones and musical relations without reflecting on the deep acuteness of truth reflected in music. We have forgotten about the questions of truth and like the deluded children of the postmodernity we believe in the story about play with letters, signs, tones and colours ...

\section{References}

1. Benjamin W (1977) Über Sprache überhaupt und über die Sprache des Menschen. Gesammelte Schriften, Band II-1, Suhrkamp Verlag, Frankfurt am Main.

2. Black David (2007) Mozart and the Practice of Sacred Music 1781-91. Harvard University Cambridge, Massachusetts.

3. Cassirer E (1955) The Philosophy of Symbolic Forms II: Mythical Thought, Oxford University Press.
4. Gianini G (2019) 'We can Build You'! Some Reflections about Human Fate and Vocation. Philos Int J 2(3): 000121.

5. Hartmann N (2017) Aesthetics. De Gruyter.

6. Hegel GWF (1975) Aesthetics/Lectures on Fine Art. Knox TM (Transl.), $2^{\text {nd }}$ (Vol.), Oxford at the Clarendon Press.

7. Kivy P (2010) Introduction to a Philosophy of Music. Oxford University Press, pp: 50,164.

8. Mcluhan M (1975) Understanding Media: The Extensions of Man. Routledge \& Kegan Paul Ltd, London.

9. Nietzsche F (1997) Twilight of the Idols, or How to Philosophize with the Hammer. Richard Polt (Transl.), Introduction by Tracy Strong, Hackett Publishing Company, Inc., Indianapolis/Cambridge.

10. Nietzsche F (1911) Early Greek Philosophy \& Other Essays. New York, The Macmillan Company.

11. Plato (1991) The Republic. $2^{\text {nd }}$ (Edn.), translated with notes and an interpretive essay by Allan Bloom, BasicBooks, a division of HarperCoWmsPublishers.

12. Plato (1995) Phaedo. Oxford University Press.

13. Armstrong AH (1953) Plotinus. London, George Allen \& Unwin Ltd, Ruskin House Museum Street.

14. Plotinus. The Six Enneads. Stephen MacKenna, Page BS (Transl.), Second Tractate.

15. Sandbote M (2005) Pragmatic Media Philosophy: Foundations of a New Discipline in the Internet Age. Andrew I (Trans.).

16. Schopenhauer A. The World As Will And Idea. Haldane RB, Kemp J (Transl.).

17. Sioran E (2010) O bogu, o muzici, o ljubavi. Edicija Braničevo, Požarevac.

18. Stravinsky I (1947) Poetic of Music. Harvard University Press, Cambridge.

19. Wagner R Art and Revolution. Wagner Library. 